\title{
Lucyna Kostuch
}

\section{Do animals have a homeland? Ancient Greeks on the cultural identity of animals}

The role of animals in ancient Greek culture has been discussed in a variety of contexts, - the relation between human and animal, the moral status of animals, animals in the works of naturalists, animals in tragedy, animals in art, zooarchaeological research. ${ }^{1}$

In the literature of ancient Greece, animals are used to represent all things that do not belong to civil society or to the Greek community: slaves, women, and foreign peoples (barbaroi). Symbolically, animals are often placed outside the country. ${ }^{2}$ However, a close reading of texts by Greek authors leads to the conclusion that this is just one side of the coin. The Greeks attributed regional identity to animals, defined by the local geography, and by the history of a region enclosed by borders. At the same time, the world of animals seemed to be ethnically diversified, for the Hellenes coined the terms "Hellenic animal," belonging to the Greek culture, and "barbaric animal," belonging to a foreign culture. In this way, Greek animals became an inalienable part of the Hellenic "national" legacy. The Greeks imagined the human world and the world of animals as a world of common borders - there were "familiar" and "unfamiliar" animals at all levels of spatial division.

This article, based primarily on literary sources, aims to answer the following questions: How did the ancient Greeks associate animals with space, geography, and their own settlements? Did they attribute nationality and territory to animals? Did they think animals missed their homelands? Could a foreign animal experience a process of cultural integration, namely Hellenization?

Animals and Greek civilization. Unlike us, the Hellenes thought about animals not only in terms of categories, such as nature, breeding, and pets. The Greeks believed the presence of animals was manifested in all aspects of life, and that they had become an integral element of Greek civilization. An animal constituted a central part of the religious cult under the control of the state. If there were around 1,500 Greek states (poleis) in the course of history, then it is hardly possible to imagine how common the image of an animal being sacrificed must have been. The rituals were also performed outside the states, e.g., in Panhellenic sanctuaries, or during times of military campaigning. Additionally, we should mention everyday bird watching, advised already by Hesiod (Works and Days 828). ${ }^{3}$ Hunting, symbolically connected with 
initiation, war, and pederasty, was popular as well (Barringer). Pictures of animals appeared on coins in many Greek states. Vases were often adorned with images of animals (Morris 184-98; Harden 25, 31). This is illustrated by the Corinthian crater from the first half of the 6th century BCE, where within a small space we can observe the following animals: four horses, two lizards, a scorpion, an eagle, a snake, an owl, a hare, and a hedgehog.

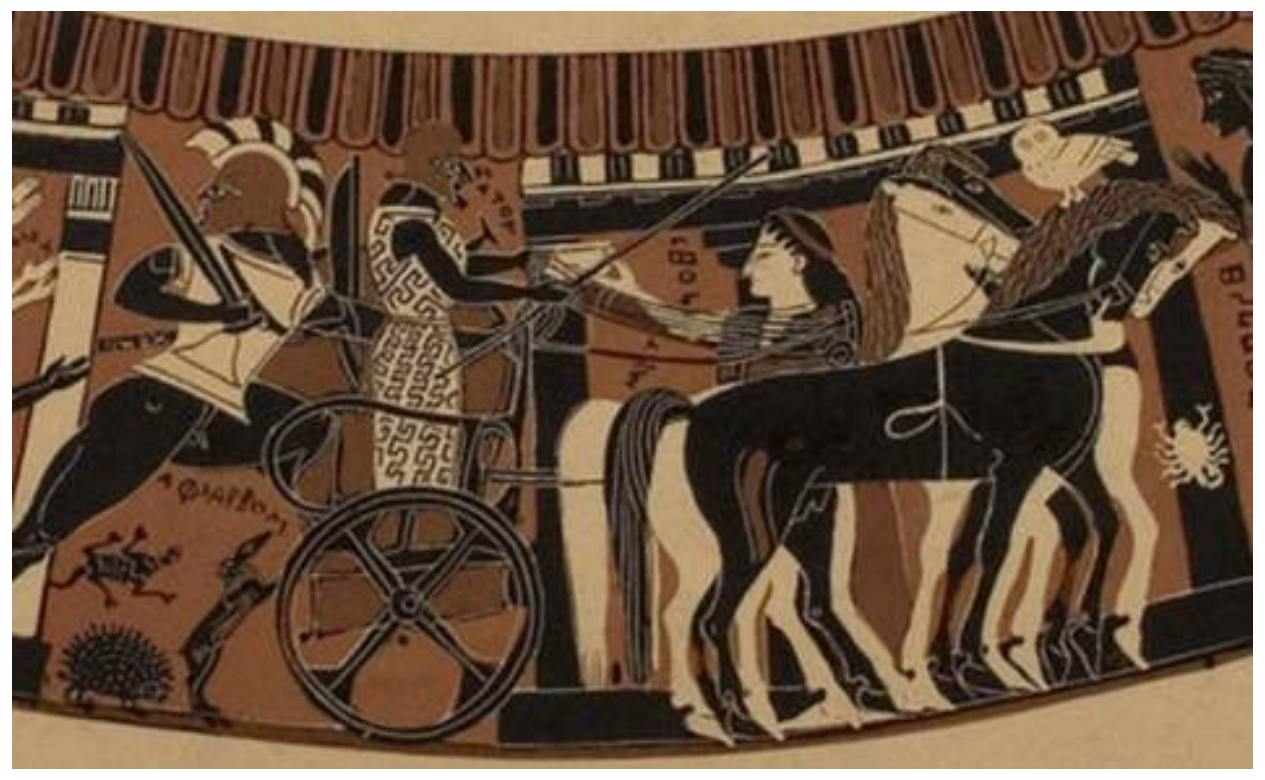

Departure of Amphiaraus. Fragment of the Corinthian Crater, 570-550 BC, Berlin, Staatliche Museen, F 1655, Lost. After A. Furtwängler and K. Reichhold, Griechische Vasenmalerei: Auswahl hervorragender Vasenbilder, Munich 1932, pl. 121.

Animals within the confines of space - crossing state borders. The ancient Greeks attempted to classify animals by dividing them into opposing groups: domestic and wild, serving humans and useless, helpful and harmful, common and exotic, living inside or outside the house, regional and Panhellenic, aquatic and terrestrial, autochthonous (indigenous) or descended from non-natives, Hellenic and barbaric, etc. They did not, however, apply any prevailing typology, and even the fundamental division into wild and domestic animals (hemeralagria) was controversial. Aristotle would undermine Plato's animal classification, but he himself did not consistently employ his own categories (Plato, Statesman 264a; Aristotle, History of Animals 488b; Parts of Animals 643b; Lloyd 17).

In ancient times, animals were mobile and would cross state borders for various reasons. Live animals would be resettled to serve in the army, as, for example, horses from Thrace, and later, elephants from India and Africa. Foreign animals would be

Humanimalia: a journal of human/animal interface studies

Volume 9, Number 1 (Fall 2017) 
placed in Greek sanctuaries; however, more often only their tusks, horns, and hides were imported. Nowadays, archaeologists are discovering the remains of crocodiles, gazelles, camels, and lions (Ekroth 337-338). Many domestic animals came from distant lands, such as monkeys, cats, peacocks, parrots, and white bears (Lazenby 247-248, 301, 305; Bodson, "Motivations" 30; Bodson, "Animaux" 10-13). Some non-native animals were trained to fight or dance before audiences. Exotic animals, including dangerous panthers, may have been diplomatic gifts or tokens of love (Bodson, "Ancient" 62, 7275; Barringer 89-101). Moreover, foreign animals were used to prepare medicine, or were sacrificed in magical practices. Oxen, mules, and asses would leave the country, and would march with the army, carrying heavy loads. Horses, and later elephants and even dogs, would follow soldiers into battle. The army would also bring some animals with it to perform rituals, for instance, sheep and goats that would later be killed on a battlefield or when encountering certain obstacles, such as gorges or rivers (Ober 174; Jameson 202-209). During a battle, the enemy's animals would be considered spoils of war and captured on the spot. Any animal could be condemned by a court for committing a crime, which meant they either would have been expelled beyond the country's borders, or their bodies would have been abandoned there.

All animals of the world and all Greek "zoologists." Undoubtedly, the Greeks were equally interested in both the animals they saw on an everyday basis and in the animals that inhabited foreign lands. They considered foreign animals and foreign people equally fascinating. This is illustrated by Herodotus's catalog of animals in Libya, which includes the following creatures: snakes, lions, elephants, bears, poisonous vipers, horned and hornless asses, antelopes, gazelles, buffalo, foxes, hyenas, porcupines, wild rams, the dictys (not identifiable), jackals, panthers, the borys (not identifiable), land crocodiles, ostriches, small snakes with one horn, three kinds of mice, weasels, the dogheaded men (kynokephaloi), headless men, and wild men (4.191-192).

The Greek authors considered it their responsibility to provide detailed descriptions of all animals. Interestingly, this duty was felt not only by naturalists, but by poets, playwrights, and historians as well. Although the aims of Homer, Herodotus, Euripides, and Aristotle differed, we must keep in mind that zoology as a distinct discipline of knowledge (techne) did not exist. All Greek authors, across genres and across time (from Homeric time to the world of Pausanias and of the Second Sophistic), were "animal experts." Sometimes we find excellent zoology in poetry, and mythological patterns in the works of naturalists. Over the centuries, Homer's epic has been used as a reference, and his descriptions of animals and their customs has been both praised and criticized. 
Aristotle confirmed or corrected the information on animals conveyed in works by Homer, Hesiod, Aesop, Aeschylus, and Herodotus. He argued that all authors should possess scientific knowledge on various topics, as, for instance, the lifespan of a dog or an ox, the castration of a boar, the change in the color and shape of a hoopoe, the diet of eagles in Mesopotamia, the reproduction of fishes in Egypt, and bull horns and horns of Libyan animals (History of Animals 575ab, 578b, 601b, 606a, 633a; Generation of Animals 756b; Parts of Animals 663b.

Three centuries later, Strabo, referring to his predecessors, called Homer the creator (archegetes) of geography, which, in his opinion, also comprised the knowledge of animals. Thus, Strabo made Homer an authority in the field of "zoology" (1.1.1-2, 1.1.16).

Sometime later, Pausanias expected to find some information on elephants in Homer's works. He blamed the absence on Homer's ignorance - it was impossible for him to imagine that the poet could have omitted them on purpose. Pausanias himself endeavored to make notes about any animal he had seen or heard of, even if it was not directly connected with the mainland of Greece that he was depicting. (Although Pausanias lived in Roman times, he described "all Greek things" - panta ta hellenika). This endeavor is illustrated by his catalog of animals with white coats or plumage. Pausanias first listed white blackbirds that were nesting in the Mount Kyllene of Arcadia, and then identified white eagles in the Mount Sipylus in Asia Minor, white boars, white bears in Thrace, white hares in Libya, and white deer brought to Rome from an unknown land (1.12.4, 8.17.3-4).

Aelian - the author of one of the most popular ancient works on animals - often quoted Homer, praising his knowledge of seals preparing for sleep and the habits of panthers (Nature of Animals 9.50, 17.43).

Between familiar and foreign - animals and interpretatio Graeca. The Greeks did more than just describe animals, they used them in metaphors to depict people. Here we encounter a surprising fact. Logic suggests that the Hellenes and the foreign tribes would be described in a similar manner: namely, the Hellenes would be represented by Greek animals, and the foreign tribes by foreign animals. However, this rule does not apply here, at all. To describe foreign peoples, the Greeks most frequently used animals quite common in the Greek world. This does not mean that they a priori considered the animals from their own country foreign. Rather, it was an instance of the Hellenes' practice, deeply rooted in their mentality, of interpreting all foreign things by means of

Humanimalia: a journal of human/animal interface studies

Volume 9, Number 1 (Fall 2017) 
Greek concepts (interpretatio Graeca). This is illustrated by the fact that in Greek utopian fantasies, distant lands were inhabited by tribes whose body parts were similar to those of the animals that the Greeks considered common. At the same time, these very lands were inhabited by extraordinary, exotic animals that bore no resemblance to Greek creatures. Additionally, there are some examples of non-native animals who experienced the process of Hellenization; in other words, the knowledge about them had become so common in the Greek world that they could be used to describe the Hellenes.

The Greeks paid attention to the sounds made by animals (Bettini 9-35) and associated them with languages of foreign peoples. Homer considered language to be the fundamental criterion in dividing the world into Hellenes and barbarians. The poet thought the Carians made "barbaric sounds" (barbarophonoi), and he associated the Trojans with bleating sheep (Iliad 2.867, 4.433-436). In fact, the onomatopoeic sound bar bar, which is considered the root of the word "barbarian," signified incomprehensible, unclear, and inarticulate sounds that resembled those of animals (Skoda; Tuplin 49-51; Gera 184-195; Munson; van Hal; Wrenhaven 24). The Greek authors found analogies between the sounds of the languages of foreign peoples and the following animal sounds: bird chirping (especially those made by swallows, pigeons, magpies and crows), bat buzzing, cicada chirping, horse neighing, dog barking and dog howling, pig grunting, frog croaking, and roaring of wild animals (Herodotus 2.57, 3.117, 4.75, 4.183; Aeschylus, Seven Against Thebes 463-464, Agamemnon 1050-1052; Sophocles, Women of Trachis 1060; Euripides, Orestes 1529; Aristophanes, Birds 199-205, Frogs 679-685; Ctesias, India FGrH 688 F 45.374; Strabo 5.2.7; Galen, Differences Between Pulses 2.5; Athenaeus $\left.659 \mathrm{a}^{5}\right)$. The barbarians' speech limitations are reflected in some popular claims of the existence of headless men, tribes with no mouths, or those with dog heads.

The theories concerning language also affected how barbarian physiognomy and customs were imagined. The most extreme forms assumed the existence of people with dog tails and furry skin, who would bark and make love on all fours. A belief that somewhere there existed people with goat horns and hooves was equally common. Additionally, it was believed that there were tribes with horse hooves or snake bodies in place of legs. Herodotus emphasizes that barbarians procreated in sacred places, similar to cattle and birds (2.64). Strabo discussed the most primitive barbarians, who would drink water like cattle until their stomachs were bloated (16.4.13; cf. Agatharchides ap. Photius 450a46). Thucydides wrote that it was customary for barbarians to carry a weapon at all times (1.6), an analogy to animals who are permanently armed with claws and fangs. 
In early literature, associating animals with barbarians was not so very radical. Homer thought that souls in Hades made sounds similar to those of bats and birds. We should stress here that "the Hades presented as place in epic poetry is a peculiarly exclusive kingdom, aristocratic and Hellenic" (Vermeule 36). This old concept can later be traced to a work by Sophocles (Oedipus Tyrannus 174). According to Aristotle, the animal - or the barbarian - language criterion was also applied to Hellenic children, who were like animals until they learned to speak (History of Animals 588ab; Problems 895a).

The method for creating animal images of barbarians was very simple. In most cases, only animals that were quite common in ancient Greece were used, such as: birds, bats, cicadas, horses, dogs, cattle, frogs, and even snakes (which were often kept in Greek houses to deter mice and rats). It is true that Herodotus described a dove from Egyptian Thebes (2.55-57), Aristophanes depicted a Thracian swallow (Frogs 679-685), and the dog-headed men were sometimes compared to monkeys; however, in general, the Greeks would use native animals to describe foreign peoples. Body parts of tribes inhabiting the most remote parts of the world would most frequently derive from those of a common dog or a goat. The same rule applied in Greek tragedies, stories filled with creatures from the barbarian world. Although in Aeschylus we can find a camel and a crocodile (Suppliants 285, 878), in Sophocles a monkey (Ichneutae 128), and in Euripides a gazelle (Bacchae 699), most of the tragedies' animals are the ones inhabiting ancient Greece, or the ones that were present in the art and literature of ancient Greece from the very beginning. In tragedy, we can find birds (eagles, pigeons, hawks, ravens, nightingales, vultures, swallows, roosters), oxen, horses, dogs, snakes, lions, sheep, wolves, goats, hares, deer, boars, pigs, dolphins, swans, bees, fish, ants, and insects (Thumiger). Even after the Greeks had familiarized themselves with exotic animals, the ones they knew well were sufficient to describe all of humanity. This is illustrated by a work on physiognomy, which is associated with Aristotle, but in fact was probably written in the 3rd century BCE (Pseudo-Aristotle, Physiognomy). The author proposes a theory, common in the Greek world, that humans' and animals' natural dispositions are analogous. As Gilhus explains, "Physiognomics (physiognomonia) is the study of the relationship between the external form of animals and humans and their inner characteristics. Animals are used as examples and symbols" (74) Pseudo-Aristotle's Physiognomy presents the following animals - listed from the least to the most frequently used in the work - a panther, a cat, a fox, a frog, a wolf, a goat, a she-goat, a sheep, a wild boar, a horse, a bull, a hare, a pig, a deer, a monkey, an ox, an ass, birds (hawk, quail, eagle, raven, rooster), a dog, and a lion.

Humanimalia: a journal of human/animal interface studies

Volume 9, Number 1 (Fall 2017) 
Among the above mentioned animals, the dominant position of a lion, as well as the quite strongly emphasized presence of a monkey, attract the most attention. The lion and the monkey are not perceived as Greek animals. How did they become part of Greek culture? Archaeological studies show that, formerly, lions might have inhabited the lands of the Balkan Peninsula. Perhaps they were brought to ancient Greece in the Mycenaean Age (Thomas). For that reason, the memory of them had been preserved until the time when the Iliad was written - a lion is "the king" of the Homeric simile (however, it is possible that lions were present in Greece in later periods as well [cf. Usener]). Thus, the lion could remain a "Greek" animal, because of Homer's account. The monkey (pithekos), known to the Hellenes since the 7th century BC (Jennison 20-21), is a second example of cultural integration in the Greek lands. Despite the fact that it was visibly non-native and was kept only as a companion, the monkey could have been used to characterize the Hellenes perfectly. The Greek authors compared ugly, shrewd, and mean people, as well as actors and dishonest orators, to monkeys (McDermott 118, 142-147; Lilja 31-38; Demont 457-479). Plato uses the monkey as a symbol of cowardice, next to the common deer (Laches 196e).

Foreign yet domesticated animals were not compelled to abandon their "cultural" identity completely. Naming animals in accordance with their country of origin made it possible to preserve a memory of their foreign descent. Hence, a rooster was sometimes referred to as persikos ornis (the Persian bird) or medikos ornis (the Median bird). The latter name was also used with reference to a peacock, because before the campaign of Alexander the Great to India, the animal had been thought to have come from Persia (Bodson, "Naming" 455, 465).

The process of "Hellenization" of non-native animals is consistent with the Greeks' ideas regarding the relationships between Hellenes and barbarians. We know that the Greeks did not dissociate themselves from barbaric cultures. On the contrary, they declared themselves "thieves," and claimed to have borrowed countless cultural goods from other peoples (Gruen 223-225, 266). Animals were a part of this process. Herodotus provided the most famous example when he wrote about a dove from Egypt who established the oldest Hellenic oracle at Dodona (2.55-57). Before learning Greek, the priestesses in the oracle first used the so-called bird speech. An analogy can also be found in The Birds by Aristophanes, where some birds sing in the barbaric language, while some have mastered the Greek language (199-200). The most remarkable Greek stallions - Xanthus, Balius, and Pegasus - were born in and grazed the meadow beside the swirl of the Okeanos, the ultimate boundary of worlds (Homer, Iliad 16.149151; Hesiod, Theogony 281-282). 
A different way of handling the cultural integration of foreign animals was to describe them as if they had derived from animals that inhabited Greek lands. According to Herodotus, the hippopotamus ("river horse") had hooves like an ox, and was equally big, but his mane, tail, and voice resembled those of a horse (2.71; cf. Aristotle, History of Animals 502a; Achilleas Tatius 4.257). "Crocodile" signified a lizard living in a river (krokodeilos potamios). Aristotle called an antelope a "horse-deer" (hippelaphos), and a rhinoceros an "Indian ass" (indikos onos) (History of Animals 498b, 499b). Pausanias named the rhinoceros the "Ethiopian bull" (Aithiopikous taurous), and the bison the "Paeonian bull" (9.21.2). A newly discovered animal was described by comparison to another foreign, yet known animal, e.g., a giraffe was called by the Greeks a "camelpanther" (kamelopardalis).

Interestingly, when Greeks were creating images of the joyful and serene place (locus amoenus) located at the end of the world, the interpretatio Graeca rule was not applied. Those lands were inhabited by animals entirely different from the Greek ones remarkably colorful birds, elephants, lions, panthers, and antelopes (Winiarczyk 18, 78, 88-89). Plato described elephants in Atlantis (Critias 114e). Also, the voices of barbaric birds were considered beautiful (Diodorus Siculus 5.43.2;8 Strabo 15.1.69), whereas the sounds made by barbarians were unpleasant to the Greek ear.

Place in space - natural and cultural differences between animals. The Hellenes were perfectly aware that the vast animal world differed depending on the place on Earth. There were even lands with no fauna - for example, a place with no birds was called aornos. However, according to the Greeks such places were scarce. Even so, in many areas some animal species were absent - in some places there were no partridges, whereas in others there were no snakes, hares, boars, deer, weasels, etc. Sometimes, this was true for the whole area, and sometimes only for a small island or river, or one mountain. Naturally, the Greeks were searching for the answer to the question: what rule governed the geographic distribution of animals? The Greeks thought that animals were assigned to one of the fundamental categories of space (land, water, mountain, or air) at the very moment they were conceived. Animals were born from the Earth and water. In the case of some animals, such as frogs or mice, their autochthony was emphasized (Campbell 233-239). The differences among animals were based on their distribution in the world. Each animal had its own place in space. Pausanias claims that when Romans first saw elephants, they did not consider them animals, most probably because they were not able to assign them to any place on Earth (1.12.3).

Humanimalia: a journal of human/animal interface studies

Volume 9, Number 1 (Fall 2017) 
This simple division was followed by a more complex construction, in which the nature of a given group of animals was influenced by the elements of geography or climate (to periechon, aer, klima). Homer was the first to introduce the basis for the science of correlations between animal physiognomy and habitat - the poet associated the size of animal horns with climate (Odyssey 4.85). At the time of Hippocrates, the role of this science was crucial, for it was believed to govern human life as well. Huge climate zones (klimata), encompassing vast territories, were established at that time, such as Europe, Asia, and Libya. Greek authors were trying to prove that Asian and Libyan animals, with only a few exceptions, grew faster, and were larger and wilder than European ones (Herodotus 3.106, 4.29; Hippocrates, Airs, Waters and Places 12; Aristotle, History of Animals 606b; Strabo 15.1.21-22; Ptolemy, Tetrabiblos 2.2). It was also believed that medicine prepared from the bodies of Asian and Libyan animals had increased properties (Pliny, Natural History 28.45). Pausanias explains that if someone traveled to distant Libya, India, or Arabia with the goal of finding animals resembling those in Greece, he would fail to find many, and the ones he would find would look different. Big snakes living in India and Libya were not snakes, but different creatures. Vipers in Ethiopia were black, for they were born in black soil. Consequently, sculptures representing the Nile were made from black stone, for the river was flowing through the land of the black Ethiopians (2.28.1, 8.24.12, 9.21.5-6). According to Aristotle, animals of the same species, as, for instance, snakes or scorpions, could be venomous in one area and non-venomous in another (History of Animals 607a). At the same time, it was thought that the appearance and behavior of animals were influenced by the elements of geography. Falling rain or water in a river would change the color of an animal's coat, but could also affect the fertility, health, or behavior of animals living in the vicinity (Aristotle, History of Animals 519a; Onesicritus, FGrH 134 F 22; Strabo 14.5.12; Pausanias 9.8.2).

The Greeks believed that animals would resemble and adjust themselves to humans with whom they shared their territory. This rule also pertained to individual species that inhabited different regions of the world. Plato discerned an analogy between the way horses and young boys were spoiled in the process of education (Apology 20a-c, 25ab). Aelian proved that Libyan horses and their keepers were similarly scruffy, as opposed to Median horses, which were neat and delicate, and to Hellenic horses, who liked cleanliness and even perfume (Nature of Animals 3.2, 16.24).

The Greeks essentially pushed wild animals outside the boundaries of their own culture. Although these animals inhabited Greek lands (Hughes 232), the Hellenes preferred to associate them with foreign countries. According to Herodotus, two rivers formed a border (horos) for lions, at Macedonia, Thessaly, and Aetolia, and prevented 
the animals from entering central Greece (7.125-126). Aristotle confirmed this view, and added that there were no panthers in Europe (History of Animals 606b). Many centuries later, Pausanias would write that lions inhabited the foothills of Mount Olympus, but only on the Macedonian side, hence they did not enter Thessaly (Pausanias 6.5.4-5). Although on numerous occasions the author mentioned bears, boars, and wolves living in the major Greek mountains, if he had been asked, he would probably have said there were no dangerous creatures in ancient Greece. There were no animals dangerous to humans even in Greek rivers. Creatures prowling for human flesh inhabited only the great rivers flowing through foreign lands. If such a beast appeared in a Greek river, it meant that it had come from the sea (Pausanias 4.34.2-3). Crete, in particular, was free of all wild animals, for this was where Zeus had grown up. No wolves, foxes, bears, snakes, or any other dangerous creatures would dare to venture onto the island. As a place where there were no wild animals, Crete represents an example of an ancient topos (Ps.-Aristotle, On Marvellous Things Heard 836b; Diodorus Siculus 4.17.3; Pliny, Natural History 8.228; Aelian, Nature of Animals 5.2).

Thus, all signs indicate that Greek animals had to conform to Greek nature, or to that of the Greek gods by analogy. For that reason, the Hellenes did not generally sacrifice wild animals (wild animals were also difficult to handle at a sacrifice in a sanctuary). Plutarch suggests that terrestrial animals became imbued with human customs through learning and imitation (On the Intelligence of Animals 23). This rule pertained to animals inhabiting various parts of the world. Barbaric animals adopted barbaric customs, just as the Greek animals were soaking up Greek culture. Even the wildest animals in the most remote lands could adopt local customs when provided with abundant food. Aristotle emphasizes this phenomenon by referring to crocodiles developing bonds with priests in some Egyptian settlements (History of Animals 608b609a).

Boundaries in animal world - animals and cultural legacy. Preserved literary sources suggest that the Greeks attributed an ability to choose a territory, as well as to understand and mark boundaries, to animals. Such boundaries defined the identity of an animal group, as long as they inhabited a given territory.

In the territories of some famous human settlements, including important ones, such as Thebes, Ephesus, Tarentum, Aigai, and Alexandria, the first steps were made by an animal who "chose" the place where the future city would be established. Sometimes the animal would be a permanent resident of a given place, and the settlers would be forced to fight a battle with the animal for its territory. Among the towns' "founders"

Humanimalia: a journal of human/animal interface studies

Volume 9, Number 1 (Fall 2017) 
were bulls, cows, mice, snakes (dragons), goats, wolves, bees, birds (crows, ravens, skylarks, pigeons, eagles, and jackdaws), or even fishes and boars (Schmid 94-101; Trumpf, 129-157; Bowie 152-165).

Greek authors would frequently observe that animals inhabited only a single part of a certain territory, and that they would change their customs, or even the color of their coats, when forced to move to a different location. Aristotle wrote that, in the vicinity of Miletus, there were two adjacent regions: one was inhabited by cicadas, but the other was not. Similarly, on one of the islands in the Ionian Sea, the territory where cicadas lived was separated by a river from the territory where they did not. The same applied to weasels on an island near Lesbos, and to moles in Boeotia (History of Animals 605b606a). Many authors described a similar behavior among cicadas in Italy. They lived in territories separated by a river, which constituted a border between two Greek colonies (Locri Epizephyrii and Rhegion). On one side of the river lived cicadas that chirped, and on the other, ones that were mute (Timaeus FGrH 566 F 43b; Antigonus, On Marvellous Things Heard 1, 2; Diodorus Siculus 4.22.5; Strabo 6.1.9; Pliny, Natural History 11.95; Pausanias 6.6.4; Aelian, Nature of Animals 5.9). Similar behavior could be observed among animals inhabiting foreign lands. Pliny the Elder gathered information on various animals, including wild asses, deer, and gazelles, who obeyed the rule of not crossing the border between their land and the neighboring one (Natural History 8.226228). According to Aristotle, animals removed from a territory they chose to inhabit would change their customs dramatically - moles would stop digging in the ground, mute frogs would begin croaking, and hares released in Ithaca were found dead, for they had attempted to return to their native home (History of Animals 606a; Mirabilia 835b). It was believed that resettled animals would change the color of their coats (Onesicritus, FGrH 134 F 22; Posidonius ap. Galen 5.463 K89). All these stories mention names of particular cities or regions enclosed by borders. We can imagine that the Greeks used such information to establish boundaries between states, or that such phenomena had a key role in settling arguments between neighboring lands.

The Greeks thought that foreign animals became attached to a given territory to an equal extent. An elephant was considered the most "patriotic" among the animals of ancient world. It was thought never to forget the charm of its homeland, hence most resettled elephants died of despair. Aelian explains: "Elephants when withdrawn from the country to which they are accustomed, though tamed at first by captivity and hunger and after that by food and a varied diet, nevertheless do not erase from their memory the spell of country that fostered them" (Aelian, Nature of Animals 10.17). 
Animals were subject to the ceremonial law stipulating that if they committed a crime, they were sent into exile, which proved that the ancient Greeks thought there was a connection between animals and certain territories. Such a law definitely existed in Attica (Hyde; MacDowell 117). Furthermore, some laws banning dogs, goats, and flies from entering sacred territories had also been preserved (Cole; McDonaugh). One Hellenic historian noted in his work that crows intentionally did not approach the Acropolis (Amelesagoras, FGrH 330 F 1).

Animals were able to identify what belonged to their territory and what did not. Herodotus provides two examples. Ibises protected the borders of Egypt from flying snakes from Arabia, and mice who destroyed quivers, bows, and shields that belonged to the Assyrians marching on Egypt $(2.75,2.141)$. A similar role was played by the lions, who attacked the Persian army and ripped camels carrying food supplies to shreds (Herodotus 7.125-126; Pausanias 6.5.4-5). We could say that the lions were protecting the very same law that banned them from crossing the borders of northern ancient Greece. Before the Macedonian attack, in one of the temples in Thebes, as a sign of mourning spiders began to spin a black web, as if they were suffering together with the Thebans. When Sulla was plundering Greek cities, he was attacked by somewhat vengeful lice (Pausanias 9.6.5; 9.33.6). In ancient times, there was a famous story about Greek birds who lived on an Italian island. They did not mind the Hellenes arriving there, but would peck all other foreigners to death (Ps.-Aristotle, On Marvellous Things Heard 836a; Lykos of Rhegium, FGrH 570 F 6; Timaeus, FGrH 566 F 53; Strabo 6.3.9; Aelian, Nature of Animals 1.1). The same rules governed the entire animal world: animals were kind to locals, but attacked strangers. However, scorpions in Caria were an exception to that rule, for they would kill only their "countrymen" (Aristotle, fr. 605 Rose, ${ }^{10}$ Antigonus, On Marvellous Things Heard 16; Pliny, Natural History 8.229).

In ancient Greece, animal customs were thought to be as regionally diversified as those of the Hellenes. As proof of this, Pausanias wrote that citizens of Pellene in Achaea excluded both men and male dogs from religious rites that worshipped Demeter. Greeks from any given region usually boasted about the extraordinary events that would occur there (Pausanias 7.27.10, 2.30.5). These anomalies were considered to be "miracle stories," but in fact they constituted a rule, and rendered a given region distinct from others (Goldhill 57). The literature provided many examples of animals with unique customs, or with an unusual color of coat. On Euboea, all oxen would be born white (Theophrastus ap. Aelian, Nature of Animals 12.36). In Elis, no mules could be born, as a result of a curse. Mares had to be rounded up beyond the borders of Elis, where they would mate with the asses, and then the mares would be led back home

Humanimalia: a journal of human/animal interface studies

Volume 9, Number 1 (Fall 2017) 
(Herodotus 4.30; Plutarch, Greek Questions 52; Pausanias 5.5.2; Aelian, Nature of Animals 5.8). Only two ravens would live at the same time in Krannon in Thessaly (Ps.-Aristotle, On Marvellous Things Heard 842b; Teopompus ap. Antigonus, On Marvellous Things Heard 15).

The same rule applied in the case of individual animals. A snake fed with biscuits in the Acropolis had nothing in common with a flying snake from Arabia, or with the snake that bit Queen Cleopatra in Egypt. Each of those snakes had a different history and culture; in short, they had different identities. When Greek literature describes stories about animals infatuated with humans, the name of the place where the event occurred, or of a region or an island, is always provided. Here are some examples: A dog fell in love with a boy in Soloi in Cilicia. A jackdaw burned with love for a young man in Sparta. A horse was sick with love for his caretaker in Athens. A ram, a gander, and a dog all fell in love with a harpist on Chios. In Alexandria, an elephant was competing with a scholar for the love of a certain florist. Plutarch confirmed that those stories were well known (On the Intelligence of Animals 18). Based on the numerous examples provided by Aelian, we can put forward the thesis that each Greek town had an animal that was infatuated with a human. Individual towns prided themselves on having animals that displayed exceptional courage or hard work. A certain Athenian dog was represented in the mural of the Stoa Poikile as a reward for the courage he displayed in the battle of Marathon. A mule from Attica received a salary from the state authorities for having volunteered to help build the Parthenon (Aelian, Nature of Animals 7.38; Plutarch, On the Intelligence of Animals 13).

Some animals and their remains constituted part of the Panhellenic legacy. When Pausanias came across some remains of the Calydonian Boar in Tegea, he could see only his frayed and decaying pelt, for his famous tusks had been taken to Rome by Augustus (8.46.1, 8.47.2). These particular tusks were not merely a curiosity, a body part of a mythical creature, but an element of the Hellenic political, literal, artistic, and religious legacy. Tusks belonging to another boar could have been an element of culture of some other peoples. According to the ancient Greeks, each animal had his homeland and customs, and could feel at home in some place on the globe.

\section{Notes}

1. See especially Lonsdale, "Attitudes Towards Animals in Ancient Greece"; Bodson, "Attitudes Towards Animals in Greco-Roman Antiquity"; Kitchell, "Man's Best Friend? The Changing Role of the Dog in Greek Society"; Zucker, Aristote et les classifications zoologiques; Gilhus, Animals, Gods and Humans: Changing Attitudes to Animals in Greek, Roman and Early Christian Ideas; Griffith, "Horsepower and Donkeywork: Equids and 
the Ancient Greek Imagination”; Thumiger, “'anagkēs zeugmat' empeptōkamen: Greek Tragedy Between Human and Animal"; Calder, Cruelty and Sentimentality. Greek attitudes to animals 600-300 BC; Konstan, "Between Appetite and Emotion, or Why Can't Animals Have Erōs"; Buxton, Myths and Tragedies in their Ancient Greek Contexts; Campbell, ed., The Oxford Handbook of Animals in Classical Thought and Life; Meyer, Aristoteles und die Geburt der biologischen Wissenschaft.

2. Cf. Vegetti, passim; duBois, esp. 78-94, 110-128; Hall 126; Cohen 4; Sassi 82-139; Lissarrague 120; Heath; Gilhus 85, 113.

3. References to well-known classical sources appear without bibliographical apparatus, following classical citation protocols. More obscure sources are cited in footnotes.

4. The initials FGrH indicate Die Fragmente der griechischen Historiker. F. Jacoby, ed. Berlin, 1923.

5. Scholars at the Dinner Table. Ch. B. Gulick, ed. 7 volumes. Harvard UP/Heinemann, 1927-1941.

6. Bibliotheca. R. Henry, Ed. 7 volumes. Les Belles Lettres, 1959-1974.

7. Leucippe and Clitophon. S. Gaselee, ed. Loeb Classical Library, 1969.

8. Bibliotheca. C. H. Oldfather, ed. Harvard UP/Heinemann, 1946-1947.

9. Claudii Galeni opera omnia. C. G. Kühn, ed. 11 volumes. Leipzig, 1821-1833.

10. Aristotelis qui ferebantur librorum fragmenta. V. Rose, ed. Leipzig, 1886.

\section{Works Cited}

Barringer, Judith M. The Hunt in Ancient Greece. The Johns Hopkins UP, 2001.

Bettini, Maurizio. Voci: Antropologia Sonora del mondo antico. Einaudi, 2008.

Bodson, Liliane. “Ancient Greek Views on the Exotic Animal.“ Arctos 32 (1998): 61-85.

Humanimalia: a journal of human/animal interface studies

Volume 9, Number 1 (Fall 2017) 
. "Attitudes Towards Animals in Greco-Roman Antiquity." International Journal for the Study of Animal Problems 4 (1983): 312-320.

- “Les Animaux dans L'Antiquité: Un gisement fécond pour l'histoire des connaissances naturalistes et des contextes culturels." Acta Orientalia Belgica 14 (2001): 127.

. "Motivations for Pet-Keeping in Ancient Greece and Rome: A Preliminary Survey." Companion Animals \& Us. Exploring the Relationships Between People and Pets. A. L. Podberscek, E. S. Paul, J. A. Serpell, eds. Cambridge UP, 2000. 27-41.

. "Naming the Exotic Animals in Ancient Greek and Latin." Animal Names. A. Minelli, G. Ortalli, G. Sanga, eds. Instituto Veneto di Scienze, Lettere ed Arti, 2005. 453480.

Bowie A. M. Aristophanes. Myth, Ritual and Comedy. Cambridge UP, 1993.

Buxton, Richard. Myths and Tragedies in their Ancient Greek Contexts. Oxford UP, 2013.

Calder, Louise. Cruelty and sentimentality. Greek attitudes to animals 600-300 BC. The Beazley Archive and Archaeopress, 2011.

Campbell, Gordon Lindsay. "Origins of Life and Origins of Species." The Oxford Handbook of Animals in Classical Thought and Life. Gordon Lindsay Campbell, ed. Oxford UP, 2014. 233-247.

Campbell, Gordon Lindsay, ed. The Oxford Handbook of Animals in Classical Thought and Life. Oxford UP, 2014.

Cohen, Beth. "Introduction." Not the Classical Ideal. Athens and the Construction of the Other in Greek Art. B. Cohen, ed. Brill, 2000. 3-20.

Cole, Susan Guettel. “Women, dogs and flies.” Ancient World 26 (1995). 182-191.

Demont, P. "Aristophane, Le citoyen tranquille et les singeries." Aristophane: La Langue, la Scène, la Cité. P. Thiercy and M. Menu, eds. Levante Editori, 1997. 457-479.

duBois, Paige. Centaurs and Amazons. Women and the Pre-History of the Great Chain of Being. U of Michigan P, 1982. 
Ekroth, Gunnel. "Animal Sacrifice in Antiquity." The Oxford Handbook of Animals in Classical Thought and Life. G. L. Campbell, ed. 324-354.

Gera, Deborah Levine. Ancient Greek Ideas on Speech, Language, and Civilization. Oxford UP, 2003.

Gilhus, Ingvid Saelid. Animals, Gods and Humans: Changing Attitudes to Animals in Greek, Roman and Early Christian Ideas. Routledge, 2006.

Goldhill, Simon. "What is local identity? The Politics of Cultural Mapping." Local Knowledge and Microidentities in the Imperial Greek World. T. Whitmarsh, ed. Cambridge UP, 2010. 46-68.

Griffith, Mark. "Horsepower and Donkeywork: Equids and the Ancient Greek Imagination." Classical Philology 101 (2006). 185-246.

Gruen, Erich S. Rethinking the Other in Antiquity. Princeton UP, 2011.

Hall, Edith. Inventing the Barbarian: Greek Self-Definition Through Tragedy. Oxford UP, 1989.

Harden, Alastair. "Animals in Classical Art." The Oxford Handbook of Animals in Classical Thought and Life. G. L. Campbell, ed. 24-60.

Heath, John. The Talking Greeks: Speech, Animals, and the Other in Homer, Aeschylus, and Plato. Cambridge UP, 2005.

Hughes, J. Donald. "The Natural Environment." A Companion to the Classical Greek World. K. H. Kinzl, ed. Blackwell, 2006. 227-244.

Hyde Walter Woodburn. "The Prosecution of Lifeless Things and Animals in Greek Law." American Journal of Philology 38.2 (1917): 152-175; 38.3 (1917): 285-303.

Jameson, M. H. "Sacrifice Before Battle." The Classical Greek Battle Experience. V. D. Hanson, ed. Routledge, 1991. 197-227.

Humanimalia: a journal of human/animal interface studies

Volume 9, Number 1 (Fall 2017) 
Jennison, George. Animals for Show and Pleasure in Ancient Rome. U of Pennsylvania P, 1937.

Kitchell, Kenneth F. "Man's Best Friend? The Changing Role of the Dog in Greek Society." PECUS. Man and Animal in Antiquity. The Swedish Institute in Rome, 2004. 177-182.

Konstan, D. "Between Appetite and Emotion, or Why Can't Animals Have Erōs." Eros in Ancient Greece. E. Sanders, Ch. Thumiger, Ch. Carey, N. J. Lowe, eds. Oxford UP, 2013. 13-26.

Lazenby, Francis D. "Greek and Roman Household Pets." Classical Journal 4.44 (1949): 245-252; 299-307.

Lilja, Saara. "The Ape in Ancient Comedy." Arctos 14 (1980). 31-38.

Lissarrague, François. "The Athenian Image of the Foreigner." Greeks and Barbarians. T. Harrisson, ed. Routledge, 2002. 101-124.

Lloyd, G. E. R. "The Development of Aristotle's Theory of the Classification of Animals." Methods and Problems in Greek Science: Selected Papers. Cambridge UP, 1991. 126.

Lonsdale, Steven H. "Attitudes Towards Animals in Ancient Greece." Greece and Rome 26 (1979): 146-159.

McDermott, William Coffman. The Ape in Antiquity. The John Hopkins UP, 1938.

McDonaugh, Christopher M. "Forbidden to Enter the Ara Maxima: Dogs and Flies or Dogflies?" Mnemosyne 52 (1999): 464-477.

MacDowell, Douglas M. The Law in Classical Athens. Thames and Hudson, 1978.

Meyer, Martin F. Aristoteles und die Geburt der biologischen Wissenschaft. Springer Verlag, 2015.

Morris, Christine. "Animals into Art in the Ancient World." A Cultural History of Animals in Antiquity. Linda Kalof, ed. Berg, 2007. 175-198. 
Munson, Rosario Vignolo. Black Doves Speak: Herodotus and the Languages of Barbarians. Cambridge UP, 2005.

Ober, J. "Hoplites and Obstacles." The Classical Greek Battle Experience. V. D. Hanson, ed. Routledge, 1991. 173-196.

Sassi, Maria Michaela. The Science of Man in Ancient Greece. U of Chicago P, 2001.

Schmid, P. B. Studien zu griechischen Ktisissagen. Paulusdruckerei, 1947.

Skoda, F. "Histoire du mot barbaros jusqu'au début de l'ère chrétienne." Actes du colloque franco-polonais d'histoire. Université de Nice, 1981. 111-126.

Thomas, Nancy R. "The Early Mycenaean Lion Up to Date." Essays in Honor of Sara A. Immerwahr. A. P. Chapin, ed. Princeton UP, 2004. 161-206.

Thumiger, Ch. "'anagkēs zeugmat' empeptōkamen: Greek Tragedy Between Human and Animal." Leeds International Classical Studies 3.7 (2008): 1-21.

Trumpf, J. “Stadtgründung und Drachenkampf.” Hermes 86 (1958): 129-157.

Tuplin, Christopher. "Greek Racism? Observations on the Character and Limits of Greek Ethnic Prejudice." Ancient Greeks. West E East. G. R. Tsetskhladze, ed. Brill, 1999. 47-75.

Usener, Knut. "Zur Existenz des Löwen im Griechenland der Antike." Symbolae Osloenses 69 (1994): 5-33.

van Hal, Toon. "Spreken als de vleermuizen. Over de Griekse en Romeinse belangstelling voor andere talen - of het gebrek daaraan." Kleio 4.38 (2009): 147-162.

Vegetti, Mario. Il coltello e lo stilo. Animali, schiavi, barbari e donne, alle origini della razionalità scientifica. Il Saggitore, 1979.

Vermeule, Emily. Aspects of Death in Early Greek Art and Poetry. U of California P, 1979.

Winiarczyk, Marek. The Sacred History of Euhemerus of Messene. Walter de Gruyter, 2013.

Humanimalia: a journal of human/animal interface studies

Volume 9, Number 1 (Fall 2017) 
Wrenhaven, Kelly L. Reconstructing the Slave: The Image of the Slave in Ancient Greece. Bristol Classical Press, 2012.

Zucker, Arnaud. Aristote et les classifications zoologiques. Peeters, 2005. 